\title{
Wzorzec osobowy pedagoga specjalnego w edukacji i terapii dziecka z zaburzeniami ze spektrum autyzmu - studium przypadku
}

\section{The Role Model of a Special Educator in Education and Therapy of Children with Autism Spectrum Disorder - Case Study}

\author{
SŁOWA KLUCZE ABSTRAKT \\ pedagog specjalny, Niniejsza publikacja obejmuje zagadnienia dotyczące osoby pedagoga \\ wzorce osobowe, specjalnego jako wzorca osobowego oraz jego znaczenia w edukacji \\ edukacja, terapia, i terapii dzieci z zaburzeniami ze spektrum autyzmu. Autorka arty- \\ autyzm kułu nad podstawie studium indywidualnego przypadku opisała \\ proces kształtowania się i znaczenia relacji, jaka powstała w kontak- \\ cie z uczennicą mającą orzeczenie o potrzebie kształcenia specjalnego \\ z uwagi na zaburzenia ze spektrum autyzmu, która dołączyła w poło- \\ wie III klasy szkoły podstawowej do klasy integracyjnej. Celem publi- \\ kacji jest ukazanie ogromnego wpływu procesu naśladowania, identy- \\ fikacji oraz modelowania i znaczenia więzi oraz samej osoby pedagoga \\ specjalnego i jego cech na proces wychowania, edukacji oraz terapii \\ dzieci ze specjalnymi potrzebami edukacyjnymi. Przedstawiony opis \\ wskazuje, iż specjaliści-nauczyciele odgrywają duże znaczenie w ży- \\ ciu swoich podopiecznych, zaś ich cechy i oddziaływanie widoczne są \\ $\mathrm{w}$ poczynionych przez uczniów postępach.
}




\title{
KEYWORDS ABSTRACT
}

special educator, This publication is about a special educator as a role model in the edurole models, cation and therapy of children with autism spectrum disorders. Based education, therapy, on the study of an individual case, the author of the article described autism the creation and meaning of a relationship that developed through contact with a 3rd grade primary school student who had a document indicating the need for special education due to autism. The student joined the integration class in the middle of the school year. The aim of the article is to show the meaning and the influence of the relationship and the person of a special educator on the process of education and therapy of children with special educational needs. The presented description shows that specialists and teachers play a huge role in the lives of their pupils, and their personality traits ad influence are visible in the progress made by the students.

\section{Wprowadzenie}

\begin{abstract}
Dobry wychowawca, który nie wttacza a wyzwala, nie ciagnie a wznosi, nie ugniata a ksztattuje, nie dyktuje a uczy, nie żąda a zapytujeprzeżyje wraz z dziećmi wiele natchnionych chwil. Janusz Korczak
\end{abstract}

Problematyka dotycząca oddziaływań wzorów osobowych i procesów leżących $\mathrm{u}$ ich podstaw stanowi od dawna obszar zainteresowań badaczy z kręgu nauk psychologicznych oraz pedagogicznych. Wpływ, jaki na uczniów wywierają osoby znaczące, w tym także nauczyciele, staje się ważnym wątkiem rozważanym zarówno przed przedstawicieli świata nauk, jak i praktyków, którzy bezpośrednio współpracują z uczniami ze specjalnymi potrzebami edukacyjnymi i rozwojowymi. Należy zatem pamiętać i mieć na uwadze, jak ważne jest oddziaływanie terapeutów na dzieci z niepełnosprawnościami.

W niniejszej publikacji kluczowe zagadnienia ukazane zostało zarówno z perspektywy naukowca, badacza, ale także praktyka, który na co dzień współpracuje z dziećmi z różnego typu niepełnosprawnościami. Opracowanie staje się zatem analizą teoretyczną, jak i rzeczywistą, zwracającą uwagę na holistyczne przedstawianie wpływu osoby pedagoga specjalnego oraz jego oddziaływania na funkcjonowanie podopiecznej. Autorka pragnie zwrócić uwagę na ważne aspekty oraz znaczenie roli, jaką pełnią nauczyciele oraz specjaliści w życiu uczniów, w także tych posiadających specjalne potrzeby edukacje i rozwojowe. Dla zobrazowania wpływu oraz tego, jak ważne jest dostosowanie wymagań i warunków kształcenia do potrzeb dzieci, jak i specyficznych 
mechanizmów identyfikacji czy modelowania, autorka zaprezentowała proces terapeutyczny dziewczynki z zaburzeniami ze spektrum autyzmu, w specyficznym momencie życia dziecka - zmiany klasy, poznania nowych kolegów i koleżanek, który okazał się być wielkim przełomem w funkcjonowaniu tego dziecka.

\section{Wzorce osobowe - wprowadzenie}

Wychowanie młodego człowieka jest zagadnieniem niezwykle złożonym, na który składa się wiele czynników. Niezwykle ważny, zwłaszcza w okresie dzieciństwa i młodości, pozostaje nurt obejmujący wpływ swoistych wzorów osobowych. Na wczesnych etapach cyklu rozwoju człowieka dotyczy on przede wszystkim modelującego wpływu rodziców na kształtowanie się społecznych zachowań dziecka i jego osobowości (Bakiera, Harwas-Napierała 2016). Jednak w kolejnych latach życia człowieka pojawiają się inne osoby, które odgrywają rolę znaczących postaci. Powoływanie się na wzór jest próbą odpowiedzi na pytanie, co jest dla nas godne szacunku, a co nie. Wzór odnosi się do wartości, a pośrednio zwraca ku pewnym wartościom osobę, która będzie ten wzór naśladować (Nowak 2015).

Efekty wpływu wzorców osobowych, nieświadomych na ogół swojej znaczącej roli w oddziaływaniu na odbiorcę (najczęściej dziecko), mogą dotyczyć różnych aspektów funkcjonowania odbiorcy. Od prostych, behawioralnych form zachowań niewerbalnych, takich jak np. gesty, mimika (mówimy wtedy najczęściej o naśladownictwie), do bardziej złożonych, oddziałujących na głębsze warstwy struktury psychicznej, na przykład na motywację do przejmowania zachowań agresywnych opisywanych jako efekt procesów modelowania i/lub identyfikacji (Bakiera, Harwas-Napierała 2016: 8). Wzory osobowe są dla ludzi tym, co „dotykalne”, bliskie, historycznie ukonkretnione. Ucieleśnione wzory skupiają uwagę przede wszystkim jako najistotniejsze punkty wartościującego odniesienia, czyli głównej życiowej orientacji (Nowak 2015). Młody człowiek dzięki takiemu postrzeganiu ma szansę na rozwój i zainspirowanie się sposobem funkcjonowania oraz zachowaniem danego modelu.

Pojęcie wzorca osobowego nie jest jednoznaczne, przede wszystkim ze względu na posługiwanie się tym terminem przez reprezentantów różnych dyscyplin naukowych, a więc historyków, socjologów, pedagogów, kulturoznawców, literaturoznawców czy psychologów. Przy tym często występuje on zamiennie z takimi pojęciami jak model, ideał, autostereotyp, wzór kulturowy, wzór biografii, autorytet itp. (Świderska-Włodarczyk 2015). Zdarza się, że można zaobserwować tendencję do bagatelizowania roli społecznego wpływu wzorów osobowych na jednostkę oraz niedostatecznego uwzględniania w genezie ludzkich zachowań, na przykład w diagnozie psychologicznej (Bakiera, Harwas-Napierała 2016). Mimo tego, wpływ owych wzorców jest niezwykle 
istotny dla rozwoju przyszłych pokoleń. Proces naśladownictwa, modelowania i identyfikowania może mieć swoje źródła w wewnętrznych motywach odbiorcy wzoru, jak również może być sterowany przez model lub inne osoby regulujące procesy społeczne (Bakiera, Harwas-Napierała 2016: 97).

Biorąc pod uwagę charakter relacji między wzorem osobowym a odbiorca, można za Jánem Grácem (1996) wyróżnić takie rodzaje wzorców jak: rodzinne, edukacyjne, partnerskie i zawodowe. Na potrzeby niniejszej publikacji, dotyczącej roli pedagoga specjalnego, zostanie opisany wzór nauczyciela, a zatem edukacyjny. Wzory edukacyjne według Jána Gráca (1996: 11) prezentowane są przez „specyficzną grupę ludzi, których osobisty przykład wypływa z ich roli wychowawczo-kształcącej”. Można do nich zaliczyć szeroko rozumianą grupę wychowawców, a więc: nauczycieli, mistrzów, instruktorów, trenerów, a nawet opiekunów rozmaitych kół zainteresowań. Co więcej, znaczenie oraz normatywność omawianego wzoru nauczycielskiego wiąże się z przypisywaniem mu standardu doskonałości, której oczekuje się w postępowaniu nauczyciela. Ów wzór powinien zawierać określone cechy, jakimi mogą wykazywać się nauczyciele, ale także kierunek nauczania nowych pokoleń pedagogów.

W opisywanym kontekście nauczycieli i ich wpływu na postawy oraz funkcjonowanie wychowanków niezwykle ważne pozostają prace Marii Grzegorzewskiej, która z myślą o przyszłych pedagogach opracowała Listy do mtodego nauczyciela, stanowiące traktat etyczny zawierający cenne wskazówki do pracy dydaktyczno-wychowawczej. Autorka, podkreślając istotę zawodu pedagoga, w sposób przemyślany stosowała termin nauczyciel jako wychowawca, chcąc uwypuklić, prawdziwie głęboki sens pracy pedagogicznej (Plutecka, 2017: 104). Grzegorzewska (1988: 51) pisała: „Aby zdziałać co wartościowego potrzeba być kimś wewnętrznie, trzeba mieć swoje własne życie, swój własny świat, trzeba mieć mocny fundament przekonań - w coś gorąco wierzyć, czemuś gorąco służyć". Słowa te wskazują dane cechy, jakimi wykazywać się powinien nauczyciel, a zatem zaangażowanie oraz pasja, determinacja, kreatywność i wewnętrzna siła.

Na kanwie podjętych rozważań można wskazać, iż przykładem niezwykle istotnego dla kształtowania się osobowości i tożsamości dziecka wzoru edukacyjnego będzie rola, jaką pełnią specjaliści, pedagogowie specjalni, co zostanie przedstawione w kolejnym podrozdziale.

\section{Pedagog specjalny jako wzorzec osobowy?}

Normatywny (typowy) przebieg rozwoju jednostki wiąże się z oddziaływaniem takich osób znaczących jak rodzice, nauczyciele, przyjaciele, współpracownicy. We wczesnym i średnim dzieciństwie osobami znaczącymi są przede wszystkim rodzice. 
Rozpoczęcie przez dziecko edukacji przedszkolnej, a następnie szkolnej, oznacza włączenie nauczycieli (wychowawców) w krąg osób znaczących. W adolescencji natomiast zdecydowanie wzrasta znaczenie rówieśników - znaczącą staje się osoba wybrana, a nie tylko taka, z którą interakcje przebiegają bez intencjonalnego wyboru. Również w dorosłości jednostka ma większy (choć nie całkowity) wpływ na wybór osób, z którymi się kontaktuje. Ich oddziaływanie rzadziej też dokonuje się w stosunkach o charakterze zależności (jak to ma miejsce w dzieciństwie), zachodzi raczej w relacjach wzajemności. W dorosłości osobami znaczącymi w rozwoju jednostki mogą być członkowie rodziny (głównie współmałżonek/konkubent, dzieci), przełożeni i współpracownicy oraz przyjaciele. Oddziaływanie osób znaczących w rozwoju człowieka dorosłego nie jest tak zasadnicze, jak w rozwoju dziecka (Bakiera, Harwas-Napierała 2016: 13).

Praca pedagoga specjalnego to praca wymagająca, polegająca na realizowaniu profesji, która stawia przed wykonawcami liczne wyzwania. Wiążą się one przede wszystkim z odpowiedzialnością (Olszewski 2017). Co więcej, wszelkie podejmowane czynności powinny być przemyślane i odpowiednio stosowane do możliwości oraz potrzeb dzieci. Co niezwykle istotne, pedagog specjalny winien być świadomy roli, jaką pełni, a więc nie tylko edukatora czy terapeuty, ale także osoby znaczącej w życiu dziecka, która staje się w przestrzeni życiowej ucznia punktem odniesienia, wzorcem, na którym dziecko może się opierać podczas ważnego etapu, jakim jest dorastanie i kształtowanie tożsamości osobowej. Ów wpływ odbywa się przede wszystkim w przebiegu procesów modelowania, naśladowania zachowania, internalizacji cech, ale także identyfikacji podopiecznego z wychowawcą. Pedagog specjalny dba o rozwój dziecka, uwzględnia jego możliwe ograniczenia, jest swego rodzaju „adwokatem” i strażnikiem potrzeb ucznia. To zaś sprzyja budowaniu relacji zaufania, wzajemnego zrozumienia oraz poczuciu bezpieczeństwa u dzieci ze specyficznymi trudnościami. W konsekwencji, terapeuta staje się osobą znaczącą dla podopiecznego, którą pragnie on naśladować, z którą się utożsamia.

Warto dodać, iż pedagog specjalny pełni nie tylko funkcję wspierającą dla dziecka ze specjalnymi potrzebami rozwojowymi i edukacyjnymi, ale także dla jego rodziny. Może przybierać rolę osoby, która pomaga zrozumieć skomplikowany świat przepisów, regulacji czy funkcjonowania instytucji. Pedagog specjalny staje się niejako pomocnikiem $\mathrm{w}$ akceptowaniu i rozumieniu specyfiki niepełnosprawności dziecka, dodatkowo może podpowiadać i instruować co do możliwych form terapii czy dalszej drogi edukacyjnej dziecka. Warto wspomnieć także o tym, że pedagog specjalny wpływa także na postrzeganie niepełnosprawności i potrzeb dziecka. To on pomaga rodzicom uwierzyć w możliwości dziecka i zwraca uwagę na trudności i ograniczenia. Wszystkie te działania sprzyjają budowaniu pozytywnego wizerunku pedagoga specjalnego w oczach dziecka oraz jego bliskich, a w konsekwencji bycia dla nich wzorem wartym naśladowania. 


\section{Dzieci z zaburzeniami ze spektrum autyzmu}

Słowo „autyzm” pochodzi od greckiego słowa autos, oznaczającego „sam”, „własne ja”. Słowo to znane już było w starożytności. Posługiwano się nim przy opisywaniu zaburzeń funkcjonowania społecznego (Mikołajczak 2017). W praktyce psychologiczno-pedagogicznej termin ,autyzm” został użyty po raz pierwszy w 1911 roku do określenia jednego z centralnych objawów schizofrenii, polegającego na zamykaniu się w sobie i braku reakcji na bodźce płynące z zewnątrz (Mikołajczak 2017). Za „ojca autyzmu" uważany jest amerykański psychiatra Leo Kanner, który w 1943 roku opisał 11 przypadków dzieci z takimi cechami jak: brak zdolności do nawiązywania relacji z innymi ludźmi, zaburzenia w komunikacji werbalnej, zachowania stereotypowe. Zespół tych objawów Kanner określił jako autyzm wczesnodziecięcy (Chrościńska-Krawczyk, Jasiński 2010). W podobnym okresie Hans Asperger opisywał podobne zaburzenia u starszych dzieci oraz nastolatków. Określił je jako naiwne i mające trudności w interakcjach społecznych, dobrze mówiące, lecz koncentrujące się wokół tematów związanych z ich zainteresowaniami (Pisula 1991).

Warto zwrócić uwagę na wzrost częstotliwości występowania zaburzeń ze spektrum autyzmu. W stosunku do badania epidemiologicznego, przeprowadzonego na populacji Wielkiej Brytanii w 1966 roku, współcześnie odnotowano ponad 20-krotne zwiększenie diagnoz w tym zakresie. Podobne zjawisko można zaobserwować na całym świecie. Szacuje się, że 1\% mieszkańców Zjednoczonego Królestwa to osoby z zaburzeniami ze spektrum autyzmu. Postępujący trend determinuje cywilizowane kraje do podejmowania badań, które pomogą lepiej zrozumieć to zaburzenie (Neuroróżnorodni 2021). Warto wspomnieć, iż w ostatnich latach obserwuje się także rozwój specjalistycznej wiedzy oraz wzrost zainteresowania społeczeństwa tematem zaburzeń ze spektrum autyzmu. Dawniej taka diagnoza oznaczała życie w samotności, brak akceptacji społecznej oraz szans rozwojowych dziecka. Obecnie sytuacja osób z zaburzeniami ze spektrum autyzmu oraz ich rodzin poprawia się, a szanse na usprawnienie funkcjonowania dziecka znacznie wzrosły (Szmania 2014). Co ważne, wraz ze wzrostem ilości analiz naukowych możliwe jest lepsze poznanie specyfiki funkcjonowania oraz opracowywanie odpowiednich metod pracy i skutecznego oddziaływania.

Najczęstsze przejawy zaburzeń ze spektrum autyzmu dotyczą trzech obszarów funkcjonowania: społecznego, a więc zaburzenia interakcji społecznych; komunikacyjnego - zaburzenia komunikacji werbalnej i niewerbalnej, oraz ograniczonych i powtarzalnych wzorców zachowania, zainteresowań, aktywności. Jednak wprowadzony w DSM-V oraz ICD-11 termin „zaburzenia ze spektrum autyzmu” odnosi się do grupy zaburzeń neurorozwojowych o wspólnej charakterystyce, dotyczącej dwóch grup objawów: trudności w społecznej komunikacji i interakcjach społecznych oraz ograniczonych i powtarzalnych wzorców zachowania, zainteresowań. Dokonano połączenia 
wcześniej wspomnianych trudności w relacjach społecznych i komunikowaniu się w jedną grupę objawów (Pisula, Omelańczuk 2020). Dodatkowo należy wspomnieć, iż wskazane trudności w sferze komunikacji językowej oraz specyficzne wzorce zachowań skutkują m.in. zaburzeniami w kontaktach międzyludzkich, porozumiewaniu się $\mathrm{z}$ innymi oraz brakiem elastyczności myślenia i zachowania. Dysfunkcje te wynikają na ogół z niedorozwoju mowy, zarówno ekspresywnego, jak i receptywnego (Pisula 2000: 21), zaś trudności w funkcjonowaniu społecznym dotyczą przede wszystkim deficytów zdolności do naprzemiennego udziału w interakcjach. Za symptomatyczne oznaki nieprawidłowości na tym polu przyjmuje się m.in.: zaburzony kontakt wzrokowy czy nieumiejętność spontanicznego wykorzystywania gestykulacji w komunikacji pozawerbalnej, ale także brak świadomości uczuć innych ludzi i empatycznego reagowania na nie (Pisula, 2000: 21). Ogólnie rzecz ujmując, osoby z zaburzeniami ze spektrum autyzmu mogą mieć trudności w budowaniu relacji z innymi ludźmi. Problem stanowią między innymi takie aspekty jak: nawiązywanie oraz utrzymywanie kontaktu wzorkowego, proszenie o pomoc, zadawanie pytań, inicjowanie rozmowy i umiejętność jej podtrzymywania, czy dzielenie się swoimi emocjami, zainteresowaniami oraz przeżyciami. Warto zwrócić uwagę, iż dzieci z zaburzeniami ze spektrum autyzmu często w czasie interakcji społecznych są pasywne lub wycofane (McClannahan, Krantz 2005).

Należy jednak wskazać, że dzieci z zaburzeniami ze spektrum autyzmu są bardzo różnorodną grupą zarówno pod względem funkcjonowania społecznego, komunikacyjnego, jak i intelektualnego. Niektóre z nich nie opanowują mowy i prezentują różne stopnie niepełnosprawności intelektualnej oraz deficyty w rozwoju społecznym. Inne mogą być całkiem komunikatywne, mogą wykazywać objawy przywiązania do osób znaczących (rodziców), przy jednoczesnych trudnościach w nawiązywaniu prawidłowych relacji z rówieśnikami oraz licznych stereotypiach i schematyzmach w zachowaniu.

Jak twierdzi Attwood (2020), wiele charakterystycznych objawów wchodzących w spektrum autyzmu ma związek z lękiem oraz stresem, przez co stanowią mechanizmy radzenia sobie z tymi trudnymi doznaniami. Zatem w momencie, gdy wzrasta poziom napięcia, nasilają się także oznaki zaburzeń charakterystycznych dla spektrum autyzmu. W takim momencie łatwo u dziecka zaobserwować wycofanie społeczne, zwiększoną potrzebę realizacji rutynowych czynności oraz rytuałów, a także wzmożoną nadwrażliwość sensoryczną czy zaangażowanie w szczególne i specyficzne zainteresowania. Ważne jednak jest, aby w takich sytuacjach obok dziecka była osoba, która pomoże mu zrozumieć i poradzić sobie z trudnymi emocjami. Nazwanie i odnalezienie źródła, następnie przyjęcie konstruktywnych strategii radzenia sobie w sytuacjach silnie nacechowanych emocjami może być trudne dla dziecka z zaburzeniami ze spektrum autyzmu. Pomocni mogą być wtedy bliscy, ale także nauczyciele, w tym 
szczególnie profesjonaliści - pedagogowie specjalni. Ten aspekt również podkreśla Attwood (2020), stwierdzając, iż w sytuacji radzenia sobie dziecka z trudnymi przeżyciami największe znaczenie ma postawa opiekunów i rodziny, którzy muszą zachować spokój, ale także wspierać podopiecznego.

\section{Opis funkcjonowania dziecka z zaburzeniami ze spektrum autyzmu na podstawie studium przypadku}

Niniejszy opis oddziaływania terapeutycznego dotyczy uczennicy, będącej podopieczną autorki tekstu. Opisywana w ramach analizy indywidualnego przypadku relacja odbywała się w formie codziennych spotkań w ramach zajęć specjalistycznych oraz lekcji edukacji wczesnoszkolnej w okresie luty-czerwiec 2021 roku. Relacja ta rozpoczęła się w specyficznym momencie dla dziewczynki: zapisania jej do klasy integracyjnej w związku z diagnozą oraz otrzymaniem orzeczenia o potrzebie kształcenia specjalnego, co stało się ważnym i przełomowym wydarzeniem w jej życiu.

Uczennica dołączyła do klasy integracyjnej w połowie III klasy (tuż po otrzymaniu orzeczenia o potrzebie kształcenia specjalnego z uwagi na zaburzenia ze spektrum autyzmu). Wcześniej nie była diagnozowana, realizowała obowiązek szkolny zgodnie z wiekiem w klasie masowej. W nowej klasie została objęta pomocą nauczyciela wspomagającego oraz zajęciami rewalidacyjnymi, w tym terapią psychologiczną, rewalidacją indywidualną oraz terapią logopedyczną. Z uwagi na konieczność stopniowej adaptacji do nowej klasy oraz widoczne trudności dziewczynki, na wniosek matki uczennica realizowała także wybrane zajęcia w formie indywidualnej. Plan uczennicy został dostosowany do możliwości psychofizycznych dziewczynki oraz jej potrzeb wynikających również ze specyfiki zaburzeń ze spektrum autyzmu.

Był to dla dziecka szczególnie trudny czas z uwagi na zmianę otoczenia, osób towarzyszących, rówieśników oraz nauczycieli. Początkowy okres adaptacji przebiegał w atmosferze lęku i wycofania. Dziewczynka nie podjęła komunikacji w formie werbalnej, unikała kontaktu wzrokowego, niechętnie wykonywała polecenia nauczyciela. Zdarzało się jej zachowywać w sposób impulsywny, niekontrolowany. Nie wykazywała zainteresowania rówieśnikami, odsuwała się od nich, siadała z daleka, unikając kontaktu. Z dogłębnego wywiadu z rodzicem oraz innymi specjalistami, którzy pracowali z dziewczynką, wynikało, że wcześniej, będąc w klasie masowej, prezentowała zachowania agresywne (kopanie, gryzienie innych dzieci) oraz autoagresywne. Dziewczynka w poprzedniej klasie rzadko posługiwała się mową werbalną, zwykle po to, aby kogoś obrazić, używała wulgaryzmów. Z wywiadu z mamą wynikało, że w domu, gdzie czuje się swobodne, wśród swojego rodzeństwa, posługuje się w sposób naturalny mową w formie werbalnej. 
W nowej klasie dziewczynka została otoczona opieką, panowała atmosfera akceptacji i zrozumienia, uczennica mogła zawsze liczyć na pomoc nauczycieli i z czasem dziewczynka zaczęła zwracać uwagę na pedagoga specjalnego - nauczyciela wspomagającego, wykonywała zalecone proste zadania, kiwała głową przecząco i potakująco na zadawane pytania. Modelowała prezentowane zachowania. Niechętnie jednak brała udział w zajęciach i aktywnościach wykonywanych wśród dzieci, w klasie. Trudno było jej pracować w tempie klasy, potrzebowała dodatkowych podpowiedzi, motywowania, wskazówek. W kontakcie indywidualnym wykonywała ćwiczenia, obserwowała zachowania nauczyciela, przyglądała się wykonywanym czynnościom, naśladowała je, przyjęła i stosowała się do przedstawionych zasad. Nauczyciele opowiadali dziewczynce o specyfice klasy, każdym dziecku, zainteresowaniach, wspólnych przedsięwzięciach.

Dużą trudność z uwagi na brak wykorzystywania mowy werbalnej stanowiła jednak diagnoza umiejętności szkolnych. Dodatkowo, uczennica często zgadywała odpowiedzi lub wskazywała na przekór błędną odpowiedź, obserwując reakcje specjalistów. Widoczne były trudności w zakresie rachunków, czytania, pisania. Dziewczynka jednak łatwo uczyła się nowych rzeczy, naśladowała, odtwarzała czynności nauczyciela, rozumiała wszystkie polecenia. Analizując zachowanie uczennicy, warto wskazać, iż z uwagi na czas pandemii i konieczność korzystania z maseczek, dziewczynka przychodziła do szkoły w odpowiednim zabezpieczeniu, jednak odmawiała zdjęcia maseczki z twarzy, nawet w sytuacjach, w których było to dozwolone i bezpieczne. Dziewczynka także nie chciała spożywać posiłków w szkole, nawet drugiego śniadania, ani też pić wody. Odmawiała także korzystania z toalety w placówce.

$\mathrm{Z}$ uwagi na duże trudności adaptacyjne oraz specjalne potrzeby edukacyjne i terapeutyczne dziewczynka większość umiejętności trenowała podczas spotkań indywidualnych, zajęć specjalistycznych oraz wybranych zajęć edukacyjnych realizowanych $\mathrm{w}$ formie indywidualnej. Zadbano także, aby mogła nawiązywać relacje rówieśnicze, codziennie spędzała czas z innymi dziećmi, w mniejszych grupach organizowano gry i zabawy integracyjne, zachęcano dziewczynkę do udziału w projektach klasowych, indywidualne w komfortowych warunkach trenowano umiejętności przydatne podczas zabaw z dziećmi. Uczennica obserwowała przyjazne zachowania innych dzieci oraz nauczycieli. Nie wyrażała ona jednak zainteresowania, raczej przyglądała się dzieciom z dystansem, przemieszczała się pomiędzy innymi asekuracyjnie, z dużym odstępem, często przy ścianie, odwrócona do niej plecami. Nie porozumiewała się z osobami z otoczenia w sposób werbalny, nauczycielom zdarzało się, że wykorzystywała gesty, ograniczoną mimikę twarzy.

Po miesięcznym okresie obserwacji oraz spotkaniu Zespołu specjalistów i matki uczennicy wyznaczono i przedyskutowano cele do pracy. Następnie zaproszono mamę dziewczynki na zajęcia rewalidacji indywidualnej, prowadzone przez nauczyciela wspierającego. Spotkanie uczennicy, jej opiekuna oraz terapeuty-pedagoga 
specjalnego wspomagającego na zajęciach terapeutycznych dziewczynki, miało za zadanie zapewnić poczucie bezpieczeństwa oraz ukazać pozytywny wizerunek, a także współpracę wszystkich osób w jej otoczeniu. Dziewczynka na tym spotkaniu po raz pierwszy wypowiedziała w sposób werbalny słowa skierowane do nauczyciela. Widać było, że przebywanie w towarzystwie pedagoga specjalnego jest dla niej komfortowe, co potwierdziła słowami. Z upływem czasu kontakt ten rozszerzał się, dziewczynka rozmawiała z pedagogiem specjalnym na osobności, ten zaś był łącznikiem pomiędzy dzieckiem a innymi specjalistami, którzy pracują z dziewczynką. Po 2 tygodniach uczennica w bezpiecznych warunkach podejmowała rozmowę ze wszystkimi nauczycielami, z którymi miała indywidualne zajęcia. Kontakt werbalny był możliwy jedynie w sytuacji indywidualnej dziewczynki z nauczycielem, osobą dorosłą. Dzięki troskliwej opiece i zapewnieniu komfortowych warunków uczennica zdobywała nowe umiejętności szkolne, nadrabiała zaległości, modelowała społecznie akceptowane zachowania, a także usprawniała zaburzone sfery, w tym szczególnie komunikację, sferę społeczną oraz emocjonalną. Dziewczynka coraz chętniej opowiadała o swojej rodzinie, zainteresowaniach, zwierzątkach domowych i emocjach. Opowiadała także o przeżyciach związanych z inną klasą i nieznanymi dziećmi. Dziewczynka zadawała wiele pytań nauczycielce, była otwarta na jej wskazówki, uwagi i zalecenia, naśladowała akceptowane zachowania. Nowa klasa uczennicy była niezwykle otwarta i cierpliwa, pozostali uczniowie zachęcali ją do kontaktu, jednak nie byli nachalni, dawali jej czas na adaptację i pokonywanie swoich lęków. Zaś matka uczennicy opowiadała, że dziewczynka opowiada w domu o szkole i swoich nauczycielach oraz kolegach i koleżankach z klasy.

Nauczyciele pracowali z dziewczynką, wykorzystując przede wszystkim metody aktywizujące, gry i zabawy, często uczennica w ramach zajęć w formie indywidualnej uczestniczyła w obserwacjach przyrodniczych, miała okazję poznawać zawody, ale także uczyć się społecznych zachowań, np. pisania, adresowania i wysyłania listów na poczcie podczas spaceru, rozpoznawania wiosennych kwiatów oraz robienia zakupów. To rozbudzało u dziewczynki ciekawość świata, nauczyciele dzielili się z nią swoimi zainteresowaniami, pasjami. Specjaliści dbali, aby lekcje były atrakcyjne i związane z zainteresowaniami dziecka, dziewczynka zaś mogła zdecydować, jaki będzie temat zajęć rewalidacyjnych, czy sama proponować ćwiczenia na zajęciach wychowania fizycznego, plastyki lub muzyki. To zaś wpisywało się w skład czynników zwiększających atrakcyjność pedagoga specjalnego jako wzorca osobowego, z którym dziewczynka tworzyła swoistą więź. Z czasem widoczne było coraz większe zaangażowanie i zainteresowanie dziewczynki edukacją, otwartość na środowisko szkolne oraz relacja pomiędzy nią a nauczycielami.

Ciekawym doświadczeniem okazał się być okres zdalnej edukacji, kiedy to uczniowie bez specjalnych potrzeb edukacyjnych odbywali lekcje z wykorzystaniem metod i technik pracy na odległość. Cały Zespół pomocy psychologiczno-pedagogicznej 
jednak postanowił, że dziewczynka dla zachowania ciągłości procesu terapeutycznego oraz z uwagi na duże trudności w zakresie obsługi sprzętu komputerowego oraz niechęci dziecka do nauki w formie online będzie odbywała zajęcia indywidualnie w formie stacjonarnej. Na zajęciach edukacji wczesnoszkolnej i innych lekcjach dziewczynka łączyła się z uczniami wraz z pedagogiem specjalnym ze szkoły z zachowaniem zasad reżimu sanitarnego. Ten okres dodatkowo wzmocnił więź łączącą pedagoga specjalnego i uczennicę. Zyskała ona dodatkowo uwagę, poczucie bezpieczeństwa i komfortu bycia w szkole oraz zrozumienie dla jej specjalnych potrzeb. Miała zapewnione optymalne warunki do nauki i rozwoju zaburzonych sfer, w tym szczególnie emocjonalnej. Co więcej, matka uczennicy doceniała zaangażowanie nauczycieli oraz córki i widziała poczynione postępy, przede wszystkim w zakresie otwartości społecznej. Okres ten przyczynił się znacznie do podniesienia atrakcyjności nauczycieli w oczach dziewczynki, którzy poświęcali jej dużo czasu i rozumieli jej potrzeby, ukazywali pozytywne zachowania i interakcje. Co ciekawe, dziewczynka nie krępowała się mówić do nauczycieli kiedy klasa miała zajęcia zdalne, co czasem owocowało tym, że komunikowała się werbalnie przy włączonych mikrofonach, to zaś dodatkowo ośmieliło uczennicę. Wraz z nauczycielką postanowiły, że po powrocie dzieci do tradycyjnej formy nauki spróbuje nawiązywać z nimi kontakt. Na początku odbywało się to w formie modelowania, nauczycielka ćwiczyła z dziewczynką możliwe sytuacje społeczne, stosowanie zwrotów grzecznościowych wobec pracowników szkoły, pomagała trenować umiejętność prowadzenia dialogu, rozszerzała dostrzeganie i rozumienie emocji, zarówno własnych, jak i innych osób, jednocześnie zapewniając poczucie bezpieczeństwa. Kiedy zatem dzieci wróciły do szkoły, uczennica była gotowa przywitać się, z czasem zaczęła grać z nimi w gry planszowe (na początku z małą grupą dziewczynek), następnie wspólnie bawić się na placu zabaw, uczestniczyć w wydarzeniach klasowych, ćwiczeniach na świeżym powietrzu, obchodach Dnia Dziecka czy spacerach. Dziewczynka stopniowo nawiązywała relacje z większą grupą dzieci z klasy, a także trenowała ze swoim pedagogiem specjalnym oraz innymi nauczycielami zachowania społeczne w kontekście innych osób, w tym także pracowników szkoły. Z czasem zaczęła się z nimi witać, odpowiadać na ich pytania, a nawet spontanicznie opowiadać coś ze swojego życia. Największą przeszkodą okazały się relacje na tle całej klasy, trudno było uczennicy odezwać się przy wszystkich, jednak zadbano o to, by poprzez wspólne gry integracyjne dziewczynka rozszerzała grono osób, z którymi się komunikuje, dzięki czemu na zakończenie klasy III była gotowa przystąpić do I Komunii Świętej oraz śpiewać podczas klasowych występów muzycznych czy dzielić się swoimi przemyśleniami oraz spostrzeżeniami.

Opisany proces terapeutyczny i zbudowana relacja nie wyeliminują, rzecz jasna, specyficznych dla zaburzeń ze spektrum autyzmu trudności, jakich doświadcza ta uczennica, jednak ukazuje, że pedagog specjalny stał się ważną osobą dla dziewczynki. 
Dzięki zbudowanej relacji zaufania, akceptacji, wsparciu i poczuciu bezpieczeństwa, a także pozytywnym cechom osobowości, jakie posiadali nauczyciele-terapeuci, uczennica poczyniła duże postępy i rozwinęła swoje umiejętności edukacyjne i społeczno-emocjonalne.

\section{Podsumowanie}

Opisany powyżej przypadek dziewczynki ukazuje, jak ważna jest rola pedagoga specjalnego w edukacji oraz terapii dzieci ze specjalnymi potrzebami edukacyjnymi i rozwojowymi. Staje się on dla nich niejako wzorem, modelem do naśladowania, ale także łącznikiem pomiędzy światem wymagań a potrzebami. Dzięki niemu uczniowie mogą trenować swoje umiejętności w bezpiecznych warunkach, a kiedy będą gotowi, mogą realizować je i budować nowe relacje z innymi osobami.

Jakimi cechami zatem winien być obdarzony pedagog specjalny, które będą sprzyjały rozwojowi uczniów ze specjalnymi potrzebami edukacyjnymi, w tym także zaburzeniami ze spektrum autyzmu, a które będą predysponowały go do bycia wzorem dla podopiecznych? Można wskazać przede wszystkim takie jak: cierpliwość, wrażliwość i zrozumienie, stałość, pewność, stabilność emocjonalna, a także aktywność oraz kreatywność. Specjalista winien cechować się także elastycznością i otwartością na potrzeby uczniów oraz odpowiedzialnością za swoje działanie, jak również świadomością wpływu na podopiecznych.

Podsumowując rozważania podjęte w niniejszej publikacji, można wskazać, iż dzięki specjalistom uczniowie z niepełnosprawnościami mogą rozwijać swoje umiejętności i budować relacje w bezpiecznych i komfortowych warunkach. Jest niezwykle ważne, aby specjaliści, terapeuci, pedagogowie mieli świadomość, że stanowią wzór osobowy dla swoich uczniów.

\section{Bibliografia}

Attwood T. (2020). COVID-19 a autyzm, [w:] Grandin T., Stock-Kranowitz C., Atwood T., Gray C., i in. (red.) Autyzm w czasie pandemii. Wskazówki i uwagi ekspertów, jak radzić sobie w trudnym czasie. Gdańsk: Grupa Wydawnicza Harmonia.

Bakiera L., Harwas-Napierała B., (2016). Wzory osobowe w rozwoju cztowieka. Poznań: Wydawnictwo Naukowe UAM.

Chrościńska-Krawczyk M., Jasiński M. (2010). Autyzm dziecięcy - wspótczesne spojrzenie. „Neurologia Dziecięca” 19(38), s. 75-78.

Grác J. (1996). Wzory osobowe oddziatujące na mtodego cztowieka - analiza teoretyczna. „Człowiek i Społeczeństwo” 14, s. 7-18. 
Grzegorzewska M. (1988). Listy do mtodego nauczyciela, cykl II. Warszawa: Wyższa Szkoła Pedagogiki Specjalnej im. Marii Grzegorzewskiej.

McClannahan L.E., Krantz P.J. (2005). Uczenie dzieci z autyzmem prowadzenia konwersacji. Metoda skryptów i ich weryfikowania. Gdańsk: Instytut Wspomagania Rozwoju Dziecka.

Mikołajczak M. (2017). Wspomaganie rozwoju dziecka z autyzmem i zespotem Aspergera. Poradnik dla rodziców i terapeutów. Warszawa: Wydawnictwo Difin.

Neuroróżnorodni (2021) nr 1 (całość poświęcona zaburzeniom).

Nowak W.M. (2015). Dobro i wzory osobowe. „Studia Philosophica Wratislaviensia” X (94), 65-76.

Olszewski S. (2017). Podmiot oddziatywań jako element obrazu realizowanej profesji $w$ definicjach formutowanych przez pedagogów specjalnych. „Rocznik Komisji Nauk Pedagogicznych" LXX, s. 81-92.

Pisula E. (1991) Dzieci autystyczne, [w]: Obuchowska I., (red). Dziecko niepetnosprawne w rodzinie. Warszawa: Wydawnictwo Szkolne i Pedagogiczne , 295-316.

Pisula E. (2000). Autyzm u dzieci. Diagnoza, klasyfikacja, etiologia. Warszawa: Wydawnictwo Naukowe PWN.

Pisula E. (2020). Zaburzenia ze spektrum autyzmu jako catościowe zaburzenia rozwoju, [w]: Grzegorzewska I., Cierpiałkowska L., Borkowska A. R., (red.) Psychologia kliniczna dzieci i mtodzieży. Warszawa: Wydawnictwo Naukowe PWN, s. 293-311.

Plutecka K. (2017). Paradygmaty pedeutologiczne w świetle pogladów Marii Grzegorzewskiej. „Przegląd Historyczno-Oświatowy” 1-2, s. 103-114.

Search D., Lloyd M., Preston M., (2006). Pomóż dziecku z autyzmem. Warszawa: Wyd. Liber.

Szmania L. (2014). Doświadczenia emocjonalne rodziców dzieci z autyzmem. „Interdyscyplinarne Konteksty Pedagogiki Specjalnej" 5, 69-91. https://doi.org/10.14746/ikps. 2014.5.05.

Świderska-Włodarczyk U. (2015). Wzorzec osobowy czy wzorzec postępowania? Przyczynek do nowej definicji formutowanej z punktu widzenia historyka na przyktadzie szlachty polskiej przetomu średniowiecza i czasów nowożytnych. „IN GREMIUM. Studia nad Historią, Kulturą i Polityką" 9, s. 41-50.

\footnotetext{
ADRES DO KORESPONDENCJI

Izabela Glac

Uniwersytet Pedagogiczny

e-mail: glac.izabela@gmail.com
} 